\title{
St John's Wort and Related Drug Interactions
}

\section{Sujit Kumar Sarker*1, Ratna Paul 2, Himel Pal ${ }^{3}$, Soe Wunna Shwe ${ }^{1}$.}

${ }^{* 1}$ Faculty of M edicine, International M edical School, M anagement \& Science University, Shah Alam, Selangor, Malaysia.

${ }^{2}$ M ohammadpur Fertility Services \& Training Centre, M ohammadpur, Dhaka, Bangladesh.

${ }^{3}$ Banaripara Upazila Health Complex, Banaripara, Barisal, Bangladesh.

\section{ABSTRACT}

Introduction: St John's wort (Hypericum perforatum L.) is a perennial plant that has transparent perforations on its leaves. It has been used as medicinal herb since ancient time.

Medicinal values: M any bioactive compounds have been isolated from St John's wort. Among those compounds hypericin and hyperforin are well studied. Both have antidepressant effects. This herb has also antineoplastic, antiviral and many other effects. Oil macerates are also used in wound healing. St John's wort extracts are used as complementary medicine in many countries.

Pharmacology: Few studies suggests that it inhibits monoamine oxidase and re-uptake of serotonin, dopamine and norepinephrine. But it causes induction of liver cytochrome oxidase enzymes and also causes many adverse effects including mania and photosensitivity.

Drug interactions: M ost of the druginteractions occur due to its enzyme induction properties. It can also reduce plasma concentration of antidepressants like amitriptyline and SSRI. It increases serotonergic effects of antidepressants such as duloxetine and venlafaxine. Data suggests that it has significant interactions with antiepileptics, combined oral contraceptives, calcium channel blockers, lipid regulating drugs (statins), antivirals and many more.

Conclusion: Although most popular use of St John's wort is mild to moderate depression, it should be taken under supervision of physician as many cases its concomitant uses are not advisable.

KEY WORDS: St John's wort, Drug interactions.

Address for correspondence: Sujit Kumar Sarker, Department of Pharmacology, Faculty of M edicine, International Medical School, Management \& Science University, Seksyen-13, 40100 Shah Alam, Selangor, Malaysia. Mobile: +60142139129, E-Mail: sujit_swapna@yahoo.com; ssswapnasujit3@gmail.com

\begin{tabular}{|c|c|c|}
\hline \multicolumn{3}{|c|}{ Online Access and Article Informtaion } \\
\hline 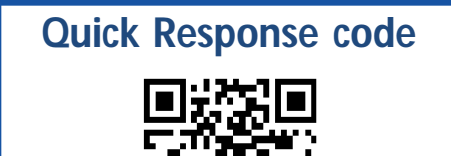 & International Jo & $\begin{array}{l}\text { ntegrative Medical Sciences } \\
\text { sciences.com }\end{array}$ \\
\hline DOI: 10.16965 ijims.2015.118 & $\begin{array}{l}\text { Received: 12-05-2015 } \\
\text { Review: 12-05-2015 }\end{array}$ & $\begin{array}{l}\text { Accepted: 24-05-2015 } \\
\text { Published: 31-05-2015 }\end{array}$ \\
\hline
\end{tabular}

\section{INTRODUCTION}

St John's wort (Hypericum perforatum L.) also known as goatweed and klamath weed is a member of the Clusiaceae family (formerly the Hypericaceae family). It is native to Europe, North America and part of Asia. It generally grows in well drained sandy soils and favors sunny exposure. Plants can grow from one to five feet long, rust-colored branches that are woody at the base. Leaves are opposite, sessile, elliptic to oblong and generally not more than one inch long. A diagnostic characteristics of the St John's wort is the presence of tiny transparent perforations on the leaves, thus the species name perforatum. This perforations can be seen when one holds the leaf up to the light source. Flowers are bright yellow with five sepals and five petals. Petals are typically twice as long as 


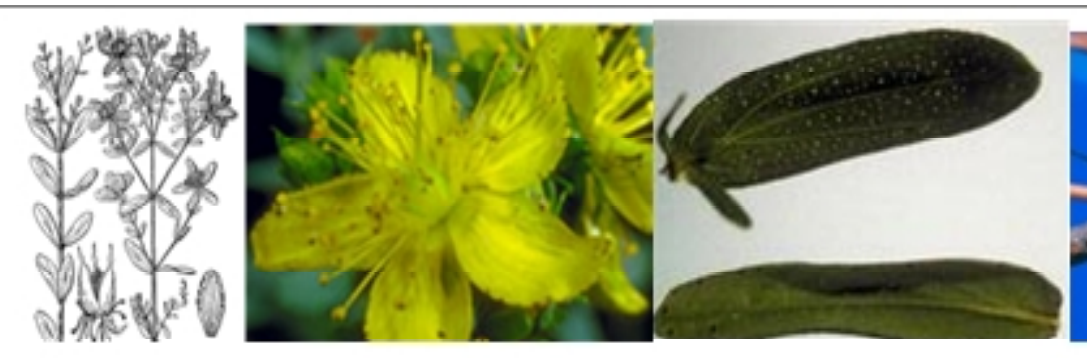

(a)St. John's wort (b)Flower
(c)Leaf

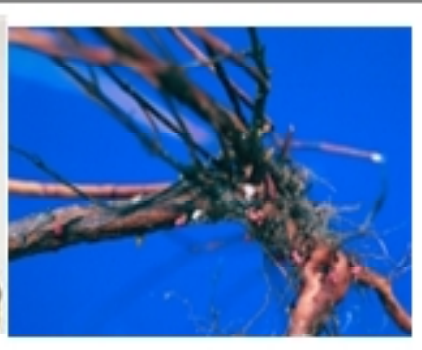

(d)Root sepals and bear black glands along the margins. An egg shaped capsule bursts at maturity and releases many gelatinous coated sticky seeds [1]. The historians consider that the name of the St John's wort was given first by Christians and owes its name to the fact that it flowers at the time of the summer solstice on or around St John's day on 24 June (nativity of Saint John the Baptist) $[2,3,5]$.

\section{MEDICINAL VALUES}

St John's wort has a 2000-year history of use as a medicinal herb [4]. Herb's use originate from the Greek herbalist of the 1st AD century, Pedanios Dioskourides, as well as from his contemporary physicians, respectively Greek and Roman, Galinos and Plenius. In the treatise, Paracelsus (1493-1541 AD), the famous Swiss alchemist and physician, has been also mentioned to be using the St. John's wort [5]. Having been administered as a remedy by the Roman military doctor Proscurides as early as the 1st century $A D$, it was mainly used for magic potions during the M iddle Ages. It was not only used to protect humans and animals against witches, demons and evil diseases, but it was also added to the fire when moulding "Freikugel" (bullets) [2].

From a phytochemical point of view, St John's wort is one of the best-investigated medicinal plants. A series of bioactive compounds has been detected in the crude material, namely flavonol derivatives, biflavones, proanthocyanidines, xanthones, phloroglucinols and naphthodianthrones. Many of the pharmacological activities appear to be attributable to the naphthodianthrone hypericin, the phloroglucinol derivative hyperforin and several flavonoids [6]. Hypericin have antitumor, antiviral (i.e., against human immunodeficiency and hepatitis ( virus), antineoplastic, and antidepressant properties.
Currently, it is widely used as an herbal remedy for the treatment of mild to moderate depression. Field-grown plant materials are generally used for the commercial production of hypericins but it has been reported that hypericin accumulation in natural plants is influenced by different ecological and environmental conditions including light intensity, nitrogen availability, temperature, seasons, and growing regions. Therefore, differences in hypericin are reported in different phytopharmaceutical preparations. [7].

The phloroglucinol derivative hyperforin has been recently shown to be a major antidepressant component. Experimental studies clearly demonstrated its activity in different behavioral models of depression. In addition to its antidepressant activity, hyperforin has many other pharmacological effects in vivo (anxiolyticlike, cognition-enhancing effects) and in vitro (antioxidant, anticyclooxygenase-1, and anticarcinogenic effects) [8].

The oil macerates of St John's Wort have a long history of medicinal use and it has been used in traditional medicine both orally and topically for centuries worldwide mainly for wound healing, ulcer and inflammation [9].

\section{PHARM ACOLOGY}

Although St John's wort has been subjected to extensive scientific studies in the last decade, there are still many open questions about its pharmacology and mechanism of action. Initial biochemical studies reported that St John's wort is only a weak inhibitor of monoamine oxidase$A$ and monoamine oxidase-B activity but it also inhibits the synaptosomal uptake of serotonin, dopamine and noradrenaline (norepinephrine) with approximately equal affinity. However, other in vitro binding assays carried out using St John's wort extract demonstrated significant affinity for 
adenosine, GABA(A), GABA(B) and glutamate receptors. In vivo St John's wort extract leads to a down regulation of beta-adrenergic receptors and an up regulation of serotonin $5-\mathrm{HT}(2)$ receptors in the rat frontal cortex and causes changes in neurotransmitter concentrations in brain areas. Recent neuroendocrine studies suggest that St John's wort is involved in the regulation of genes that control hypothalamicpituitary-adrenal axis function [6]. Among the bioactive compounds hyperforin has been shown to inhibit re-uptake of neurotransmitters like serotonin, noradrenaline, dopamine, gammaaminobutyric acid (GABA), L-glutamate $[8,10]$. Its mechanism of action seems to be related to sodium conductive pathways, leading to an elevation in intracellular $\mathrm{Na}(+)$ concentration [8]. Hyperforin seems to be responsible for the induction of liver cytochrome oxidase enzymes and intestinal P-glycoprotein [8].

St John's wort has a long application history in treating depression. Combinations of St John's Wort and tricyclic antidepressants (TCA) compared to tricyclic antidepressants alone had significant effect on mild to moderate depression improvement. This combination group (St J ohn's wort with TCA) had improved in quality of sleep and the increase of energy [11].

Majority of people who take this popular overthe-counter preparation do so without formal psychiatric evaluations, so risk of St John's wort induced mania may be significant $[12,13,14]$. Physicians should screen patients for a history of hypomania or mania before recommending use of St John's wort for depression [12].

Hypericin, a bioactive compound of St John's wort is reported to be responsible for the photosensitive reactions $[15,16]$. Hypericin displays absorption within the ultraviolet (UV) A1 spectrum and there may therefore be a potential for phototoxicity if taken during high dose UVA1 therapy [16].

One case of liver damage also reported after use of herbal product of St John's wort [17] and one case of hepatocellular carcinoma (HCC) with 6 months history of St John's wort has been reported [18].

\begin{tabular}{|c|c|c|}
\hline Drug & Mechanism / effects / caution & Drugs considered for interaction with St John's w ort \\
\hline St John's wort & $\begin{array}{l}\text { St John's wort is an enzyme } \\
\text { inducer and induces metabolism } \\
\text { of concomitantly used drugs, } \\
\text { possibly reduces their plasma } \\
\text { concentration and therapeutic } \\
\text { effects. }\end{array}$ & $\begin{array}{l}\text { Analgesics: methadone } \\
\text { Antiarrhythmics: dronedarone } \\
\text { Antibacterials: telithromycin (avoid during and for } 2 \\
\text { weeks after St John's wort) } \\
\text { Anticoagulants: coumarins, da bigatran } \\
\text { Antidepressants: amitriptyline } \\
\text { Antifungals: voriconazole } \\
\text { Antipsychotics: aripiprazole } \\
\text { Antivirals: atazanavir, darunavir, efa virenz, } \\
\text { fosamprenavir, indinavir, lopinavir, nevirapine, ritonavir, } \\
\text { saquinavir, maraviroc, tipranavir, rilpi virine } \\
\text { Anxiolytics \& hypnotics: mi dazolam (oral) } \\
\text { Calcium channel blockers: aml odipine, felodipine, } \\
\text { nifedipine, vera pamil } \\
\text { Cardiac glycosides: digoxin } \\
\text { Ciclosporin } \\
\text { Cytotoxics: axitinib, bosutinib, crizotinib, everolimus, } \\
\text { vinflunine, imati nib, vandetanib, vismodegib, eribulin, } \\
\text { irinotecan } \\
\text { Diuretics: eplerenone } \\
\text { Ivabradine } \\
\text { Ivacaftor } \\
\text { Lipid regulating drugs: simvastatin } \\
\text { Oestrogens } \\
\text { Progestogens } \\
\text { Tacrolimus } \\
\text { Theophylline } \\
\text { Ulcer healing drugs: omeprazole }\end{array}$ \\
\hline St John's wort & $\begin{array}{l}\text { St John's wort increases } \\
\text { serotonergic effects }\end{array}$ & $\begin{array}{l}\text { Antidepressants: duloxetine, venlafaxine, SSRI } \\
\text { Dapoxetine (St John's wort shouldn't be started until } 1 \\
\text { week after stopping dapoxetine, avoid dapoxetine for } 2 \\
\text { weeks after stopping St John's wort) } \\
\text { 5-HT1- receptor agonists }\end{array}$ \\
\hline St John's wort & $\begin{array}{l}\text { Avoid concomitant use advised by } \\
\text { manufacturer }\end{array}$ & $\begin{array}{l}\text { Antiepileptics } \\
\text { Antimalarials: artemether with lumefantrine, piperaquine } \\
\text { with arteni mol } \\
\text { Antivirals: el vitegravir, etravirine, tel aprevir } \\
\text { Aprepitant } \\
\text { Cytotoxics: cabazitaxel, gefitinib, la patinib, vemurafenib } \\
\text { Ulipristal }\end{array}$ \\
\hline St John's wort & $\begin{array}{l}\text { Possibly increases risk of } \\
\text { convulsions }\end{array}$ & Atomoxetine \\
\hline
\end{tabular}

Table 1: Summary of possible drug interactions of St John's wort [19, 20]. 


\section{DRUG INTERACTIONS}

Although St John's wort is a popular herbal remedy for treating depression, it induces drug metabolizing enzymes and it has important interactions with conventional drugs, including antidepressants. The amount of active ingredient also varies among different preparations of St John's wort and that can change the degree of enzyme induction. If a patient stop taking St John's wort, the concentration of interacting drugs may increase leading to toxicity [19]. Table-1 summarizes possible drug interactions of St John's wort.

\section{CONCLUSION}

St John's wort is a herb and its flowers and leaves are commonly used for medicinal purpose. It has many drug interactions with conventional medicines. Although it is popularly used for mild to moderate depression, still its efficacy is not conclusive. Further pharmacokinetics studies are also required for its rational use. Therefore clinical uses of St John's wort including its extract should be under supervision of a registered physician.

\section{REFERENCES}

[1]. Jane M angold, Roger Sheley and M elissa Brown. St. Johnswort: identification, biology and integrated management. M ontana State University Extension. [updated 2009 August] Available from: http:// www.msuextension.org/invasiveplantsM angold/ documents/Publications_bulletins/ St.\%20Johnswort.pdf

[2]. Pöldinger W. History of St. J ohns wort. Praxis (Bern 1994) 2000;89(50):2102-9.

[3]. Wikipedia. [updated $2015 \mathrm{M}$ ay 10] Available from: http://en.wikipedia.org/wiki/John_the_Baptist

[4]. Vorbach EU, Arnoldt KH, Wolpert E. St John's wort: a potential therapy for elderly depressed patients? Drugs Aging 2000;16(3):189-97.

[5]. Istikoglou Cl, Mavreas V, Geroulanos G. History and therapeutic properties of Hypericum Perforatum from antiquity until today. Psychiatriki 2010;21(4):332-8.

[6]. Butterweck V. Mechanism of action of St John's wort in depression : what is known? CNS Drugs 2003; 17(8):539-62.

[7]. Murthy HN, Kim YS, Park SY, Paek KY. Hypericins: biotechnological production from cell and organ cultures. Appl Microbiol Biotechnol 2014;98(22):9187-98.
[8]. Zanoli P. Role of hyperforin in the pharmacological activities of St. John's Wort. CNS Drug Rev 2004; 10(3):203-18.

[9]. Orhan IE, Kartal M, Gülpinar AR, Yetkin G, Orlikova $B$, Diederich M, Tasdemir D. Inhibitory effect of St. Johnxs Wort oil macerates on TNFá-induced NF-êB activation and their fatty acid composition. J Ethnopharmacol 2014;155(2):1086-92.

[10]. M üller WE.Current St John's wort research from mode of action to clinical efficacy. Pharmacol Res. 2003;47(2):101-9.

[11]. Pakseresht S, Boustani H, Azemi ME, Nilsaz J, Babapour R, Haghdust M R. Evaluation of Pharmaceutical Products of St. John's Wort Efficacy Added on Tricyclic Antidepressants in treating Major Depressive Disorder: A Double Blind Randomized Control Trial. Jundishapur J Nat Pharm Prod 2012;7(3):106-10.

[12]. Nierenberg AA, Burt T, M atthews], Weiss AP. Mania associated with St. John's wort. Biol Psychiatry 1999,46(12):1707-8.

[13]. Fahmi M, Huang C, Schweitzer I. A case of mania induced by hypericum. World J Biol Psychiatry 2002;3(1):58-9.

[14]. Güzelcan Y, Scholte WF, Assies ], Becker HE. Mania during the use of a combination preparation with St. John's wort (Hypericum perforatum). Ned Tijdschr Geneeskd 2001;145(40):1943-5.

[15]. Barnes], Anderson LA, Phillipson JD. St John's wort (Hypericum perforatum L.): a review of its chemistry, pharmacology and clinical properties. J Pharm Pharmacol 2001;53(5):583-600.

[16]. Beattie PE, Dawe RS, Traynor NJ, WoodsJA, Ferguson J, Ibbotson SH. Can St John's wort (hypericin) ingestion enhance the erythemal response during high-dose ultraviolet $\mathrm{A} 1$ therapy? $\mathrm{Br} J$ Dermatol 2005; 153(6):1187-91.

[17]. Agollo M C, M iszputen SJ, Diament J. Hypericum perforatum-induced hepatotoxicity with possible association with copaiba (Copaifera langsdorffii Desf): case report. Einstein (Sao Paulo) 2014;12(3):355-7.

[18]. Lampri ES, loachim E, Harissis H, Balasi E, M itselou A, Malamou-Mitsi V: Pleomorphic hepatocellular carcinoma following consumption of hypericum perforatum in alcoholic cirrhosis. World J Gastroenterol 2014,20(8):2113-6.

[19]. BM A \& Royal Pharmaceutical Society. Appendix-1: Interactions. British National Formulary 2014;67: 245,955.

[20]. John R. Horn. Important drug interactions and their mechanisms. In: Bertram G. Katzung, Susan B. Masters, AnthonyJ. Trevor, editors. Basic \& Clinical Pharmacology. New York: Mc Graw Hill;2013.p11491162.

[21]. Drugs.com. St.John's wort. [updated 2015 April 1]. Available from: http://www.drugs.com/cdi/st-johns-wort.html 
[22]. USDA National Agricultural Library. St. Johnswort. [updated 2015 April 17]. Available from: http:// ww w.invasivespeciesinfo.gov/plants/ stjohnswort.shtml\#cit

[23]. Invasive plant atlas from the United States. Common St. Johnswort. [updated 2015 April 24]. Available from: http://www.invasiveplantatlas.org/ subject.html?sub=4411

[24]. Rx list. [updated $2015 \mathrm{M}$ ay 13] Available from: http://www.rxlist.com/st_johns_wort/ supplements.htm

[25]. Knüppel L, Linde K. Adverse effects of St. John's Wort: a systematic review. J Clin Psychiatry 2004;65(11):1470-9.

How to cite this article: Sujit Kumar Sarker, Ratna Paul, Himel Pal, Soe Wunna Shwe. St John's Wort and Related Drug Interactions: A Review. Int J Intg M ed Sci 2015;2(5):128132. DOI: $10.16965 /$ ijims.2015.118
[26]. Paul Hammerness, Ethan Basch, Catherine Ulbricht, E.-P. Barrette, Ivo Foppa, Samuel Basch et al., St. John's Wort: A Systematic Review of Adverse Effects and Drug Interactions for the Consultation Psychiatrist. Psychosomatics 2003;44(4):271-282.

[27]. Hina Laeeque, Theresa L. Charrois, Sunita Vohra. Adverse Effects and Drug Interactions Relating to Use of St. John's Wort. Canadian Pharmacists Journal 2006;139:30-33.

[28]. Klaus Linde, M ichael Berner, M atthias Egger, Cynthia Mulrow. St John's wort for depression: Metaanalysis of randomised controlled trials. British Journal of Phychiatry 2005;186:99-107.

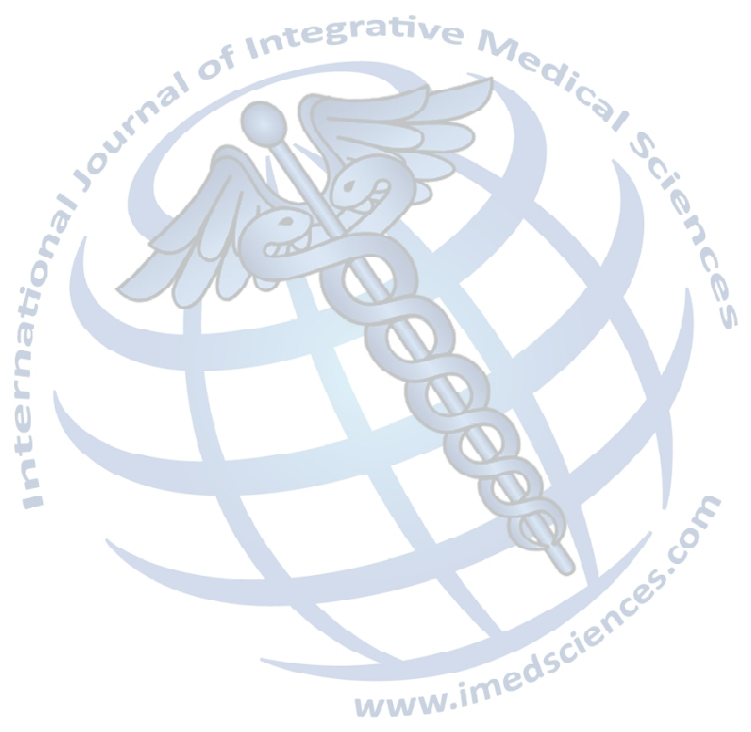

